\title{
Growth hormone and melatonin prevent age-related alteration in apoptosis processes in the dentate gyrus of male rats
}

\author{
R. A. Kireev $\cdot$ E. Vara $\cdot$ J. A. F. Tresguerres
}

Received: 16 November 2012/Accepted: 7 July 2013/Published online: 13 July 2013

(C) The Author(s) 2013. This article is published with open access at Springerlink.com

\begin{abstract}
It has been suggested that the age-related decrease in the number of neurons in the hippocampus that leads to alterations in brain function, may be associated with an increase in apoptosis due to the reduced secretion of growth hormone $(\mathrm{GH})$ and/or melatonin in old animals. In order to investigate this possibility, male Wistar rats of 22 months of age were divided into three groups. One group remained untreated and acted as the control group. The second was treated with growth hormone (hGH) for 10 weeks $(2 \mathrm{mg} / \mathrm{kg} / \mathrm{d} \mathrm{sc}$ ) and the third was subjected to melatonin treatment $(1 \mathrm{mg} / \mathrm{kg} / \mathrm{d})$ in the drinking water for the same time. A group of 2-months-old male rats was used as young controls. All rats were killed by decapitation at more than 24 month of age and dentate gyri of the
\end{abstract}

R. A. Kireev · J. A. F. Tresguerres

Department Physiology, Medical School,

University Complutense of Madrid, Madrid, Spain

R. A. Kireev ( $\square)$

Laboratory of Experimental Endocrinology,

Department of Physiology, School of Medicine,

Complutense University, Avda Camon y Cajal s/n.,

28040 Madrid, Spain

e-mail: rakireev@gmail.com

E. Vara

Department Biochemistry and Molecular Biology,

Medical School, University Complutense of Madrid,

Madrid, Spain hippocampi were collected. Aging in the dentate gyrus was associated with an increase in apoptosis promoting markers (Bax, Bad and AIF) and with the reduction of some anti-apoptotic ones (XIAP, NIAP, Mcl-1). Expressions of sirtuin 1 and 2 (SIRT1 and 2) as well as levels of HSP 70 were decreased in the dentate gyrus of old rats. GH treatment was able to reduce the pro/ anti-apoptotic ratio to levels observed in young animals and also to increase SIRT2. Melatonin reduced also expression of pro-apoptotic genes and proteins (Bax, Bad and AIF), and increased levels of myeloid cell leukemia-1 proteins and SIRT1. Both treatments were able to reduce apoptosis and to enhance survival markers in this part of the hippocampus.

Keywords Aging - Dentate gyrus - Apoptosis · Sirtuins · Growth hormone - Melatonin

$\begin{array}{ll}\text { Abbreviation } & \\ \text { NIAP } & \text { Neuronal inhibitor apoptosis protein } \\ \text { XIAP } & \text { X-linked inhibitor of apoptosis protein } \\ \text { AIF } & \text { Apoptosis-inducing factor } \\ \text { Mcl-1 } & \text { Myeloid cell leukemia-1 } \\ \text { SIRT1 and 2 } & \text { Sirtuin 1 and 2 } \\ \text { HSPs } & \text { Heat shock proteins } \\ \text { GH } & \text { Growth hormone } \\ \text { Bad } & \text { Bcl-2-associated death promoter } \\ \text { Bax } & \text { Bcl-2-associated X protein } \\ \text { Bak } & \text { Bcl-2 homologous antagonist/killer } \\ \text { Endo G } & \text { Endonuclease G } \\ \text { PI3K } & \text { Phosphatidylinositol 3-kinases }\end{array}$




$\begin{array}{ll}\text { AKT } & \begin{array}{l}\text { Protein kinase B (PKB), is a serine/ } \\ \text { threonine-specific protein kinase }\end{array} \\ \text { cAMP } & \begin{array}{l}\text { Cyclic adenosine monophosphate } \\ \text { IGF-I }\end{array} \\ \text { Insulin like growth factor } \\ \text { CNS } & \text { B-cell lymphoma 2 } \\ & \text { Central nervous system }\end{array}$

\section{Introduction}

The hippocampus is a target of age-related physiological and structural changes. Alterations in the hippocampus during aging are paralleled by behavioral and functional deficits in hippocampus-dependent learning and memory tasks (Rosenzweig and Barnes 2003). Recent microarray studies of hippocampal gene expression, identified several aging-dependent upregulated processes, including lipid catabolism, proteolysis, cholesterol transport, and myelinogenesis in normally aging rats (Rowe et al. 2007; Kadish et al. 2009).

In humans, apoptosis occurs in the developing nervous system to eliminate neurons with erroneous or inadequate projections (Chan et al. 2002), whereas enhanced apoptosis in the adult brain is also characteristic of several pathologies of the central nervous system (CNS) (Mattson 2006; Kim and Sun 2011). It has been suggested that the decrease in the number of neurons by apoptosis may be associated with trophic factor(s) deprivation (Ambacher et al. 2012) or with the absence or reduction of anti-apoptotic proteins such as B-cell lymphoma 2 (Bcl-2) (Allsopp et al. 1993). Many apoptosis-related factors have been demonstrated to be up-regulated in the immature brain, such as caspase-3, Apaf-1 and Bcl-2-associated X protein (Bax) (Ota et al. 2002; Troy et al. 2011). Inhibitor of apoptosis (IAP) family of proteins like neuronal inhibitor apoptosis protein (NIAP), X-linked inhibitor of apoptosis protein (XIAP), and cIAP-2 play also a role in the regulation of neuronal death and in several models of disease. NIAP directly inhibits caspase-3, -7, and -9 and XIAP directly inhibits also caspase-3 and caspase-7 (Prunell and Troy 2004).

Sirtuin1 (SIRT1) is a mammalian nicotinamide adenine dinucleotide (NAD)-dependent histone deacetylase (HDAC) that down-regulates the acetylation levels of many regulatory proteins involved in energy homeostasis, DNA repair, cell survival, and lifespan extension (Kwon and Ott 2008). SIRT1 has been shown to be associated with reduced apoptosis, whereas inactivation of SIRT1 could on the contrary promote translocation of Bax from the cytosol to mitochondria (Cohen et al. 2004). SIRT1 also protects against amyloid- $\beta$ toxicity in cell culture and neurodegeneration in the p25/CDK5 mouse model, which recapitulates aspects of Alzheimer's disease pathology and tauopathy (Kim et al. 2007).

Activity of the growth hormone $(\mathrm{GH}) /$ insulin like growth factor (IGF-I) axis undergoes an age-related decline, including reduced spontaneous GH secretion and circulating IGF-I levels, which may reach values that are similar to those found in GH-deficient patients (Ghigo et al. 2000). In both elderly and GH-deficient adults, this decreased GH/IGF-I activity has been associated with changes in body composition and metabolism, altered sleep patterns and reduced cognitive function. GH replacement therapy has been found to improve some age-dependent cognitive functions, such as memory, motivation, or mental processing speed (Nass et al. 2009; Quik et al. 2010). In a dwarf rat model with reduced levels of serum $\mathrm{GH}$ and IGF1 beginning before adolescence, early intervention with GH for 10 weeks starting around puberty was reported to ameliorate age-related pathology in later life and increase lifespan (Sonntag et al. 2005). A significant decrease has been observed in the density of GH binding with increasing age (over 60 years old) in the choroid plexus, hypothalamus, hippocampus, pituitary, and putamen (Lai et al. 1993). Progressive loss of activated precursors and neurons has been shown to correlate with an age-dependent decline in GH secretion in both rodents and humans (NievesMartinez et al. 2010). Knock-down of GH by gene silencing in cells of this cultured embryonic neural retina cell line, using NR-cGH-1 siRNA, correlates with the increased appearance in the cultures of cells with apoptotic nuclear morphology (Sanders et al. 2010).

Melatonin binding sites do also exist in the hippocampus of several mammals. MT1 and MT2 receptors have been localized in the dentate gyrus, CA3 and CA1 regions and subiculum of the hippocampus (Musshoff et al. 2002). Melatonin production by the pineal is severely restricted in advanced age in humans as well as in experimental animals. Other studies have demonstrated an age-related decrease of 2-[125]-iodomelatonin binding and MT1 mRNA in 
the CNS of rat and mice (Pandi-Perumal et al. 2008). For instance, Laudon et al. (1988) reported an agerelated lowering in the density of melatonin binding sites in discrete rat hypothalamic and hippocampal areas. Many experimental data have demonstrated that, melatonin is an anti-apoptotic mediator. So, melatonin supplementation was able to inhibit apoptosis in amyloid $\beta$-peptide (A $\beta$ ) injury in hippocampal neurons (Shen et al. 2002) and to suppress NOinduced apoptosis by stimulating of Bcl-2 expression in immortalized pineal PGT- $\beta$ cells (Yoo et al. 2002).

In a previous publication, we have demonstrated that the number of neurons in the hilus of the dentate gyrus was significantly decreased during aging and that chronic GH treatment was able to prevent this neuronal loss. These findings indicated that $\mathrm{GH}$ administration might prevent some of the aging associated with this hippocampal area alteration (Azcoitia et al. 2005). Since no increase in neurogenesis was detected, the maintenance of the neuronal population could be probably due to a reduction of apoptosis. However, previous data supporting this potential pathway were obtained only in whole rat brain (Tresguerres et al. 2008) but not specifically in the denate gyrus.

So, the aim of the present study was to investigate if chronic treatments with exogenous $\mathrm{GH}$ and melatonin were able to reduce the increased apoptosis processes observed in the dentate gyrus of old male Wistar rats, leading to a reduction in the total number of neurones in this CNS area after 22 months of age in these animals.

\section{Materials and methods}

Animals

Male Wistar rats of 2 (6-8\% lifespan) and 22 months (70-75\% lifespan) of age were used. Animals were obtained from Harlan Iberica (Barcelona, Spain) and maintained at a constant temperature $\left(21 \pm 2{ }^{\circ} \mathrm{C}\right)$ on a 12-h light/dark cycle and standard laboratory rat chow (A04 Panlab, Barcelona, Spain) with free access to food and water. Rats were treated according to the guidelines of the European Community Council Directives 86/6091 EEC. The average lifespan of Wistar rats in the laboratory was $\sim 34-36$ months.
Old animals were divided in three groups at 22 months of age. Untreated control rats (group 1), rats treated with hGH, (group 2) and animals treated with melatonin (group 3). Rats were sacrificed in groups of $n=12 / 13$ at more than 24 months of age.

Melatonin (Actafarma, Madrid, Spain) was given in the drinking water at a dose of $1 \mathrm{mg} / \mathrm{kg} /$ day for 10 weeks. A fresh melatonin solution was prepared 3 times per week, depending on the water consumption and the weight of the animals to obtain a melatonin dose of $1 \mathrm{mg} / \mathrm{kg} /$ day. Water bottles were covered with aluminium foil to protect them from light, and the drinking fluid was changed 3 times weekly. Melatonin was given over $24 \mathrm{~h}$, but we need to take into account that during the day these animals were sleeping, so, normally more than $80 \%$ of the water was drunk during there activity phase, in the night.

Treatment with hGH (Sandoz, Germany) was performed twice daily by sc injections at a dose of $1 \mathrm{mg} / \mathrm{kg}$ for 2.5 months (Azcoitia et al. 2005; Tresguerres et al. 2008). We need to take into consideration that the GH used was of human origin, so that the response was not the same as for rat GH. On the other hand, small animals needed a much higher dosage than humans, as was demonstrated by Mordenti and Chappell (1989).

Untreated animals were injected with saline twice daily. A group of 2-months-old animals $(n=12)$ was used as reference control. After the treatment period, animals were sacrificed by decapitation and dentate gyrus samples were immediately dissected. Dentate gyrus was dissected under a binocular as described (Lein et al. 2004; Hagihara et al. 2009), immediately frozen in liquid nitrogen, and stored at $-80{ }^{\circ} \mathrm{C}$ until use.

Extraction of tissue samples and determination of HSP 70

Dentate gyrus were quickly dissected and frozen in liquid nitrogen. Frozen organ samples were transferred to 5-ml polypropylene tubes containing $1 \times$ Extraction reagent $\left(4{ }^{\circ} \mathrm{C}\right)$ with protease inhibitors (0.1 mM PMSF, $1 \mu \mathrm{g} / \mathrm{ml}$ leupeptin, $1 \mu \mathrm{g} / \mathrm{ml}$ aprotinin, $1 \mu \mathrm{g} / \mathrm{ml}$ pepstatin). Samples were homogenized for $30 \mathrm{~s}$ with an electrical homogenizer (Polytron; Brinkmann Instruments, Westminster, NY, USA) and later centrifuged at $21,000 \times g\left(10 \mathrm{~min}, 4^{\circ} \mathrm{C}\right)$. The 
supernatant collected and were stored at $-80{ }^{\circ} \mathrm{C}$ until assayed for the quantitative presence of HSP 70 .

HSP 70 was measured with an ELISA kit according to the manufacturer's instructions (Assay designs, Stressgen, MI, USA, catalog number: EKS-700B).

A mouse monoclonal antibody specific for inducible HSP 70 is pre-coated on the well of the provided HSP 70 Immunoassay Plate. Inducible HSP 70 is captured by the immobilized antibody and is detected with a HSP 70 specific rabbit polyclonal antibody. The rabbit polyclonal antibody is subsequently bound by a horseradish peroxidase conjugated anti-rabbit $\mathrm{IgG}$ secondary antibody. The assay is developed with tetramethylbenzidine (TMB) substrate and blue color develops in proportion to the amount of captured HSP 70. The color development is stopped with acid stop solution. The intensity of the color is measured in microplate reader at $450 \mathrm{~nm}$. HSP 70 concentrations from the sample are quantitated by interpolating absorbance reading from a standard curve generated with the calibrated HSP 70 protein standard provided.

\section{Western blotting analysis}

Western blots were used to measure the protein expression of Bax, Bcl-2-associated death promoter (Bad), myeloid cell leukemia-1 (Mcl-1) and Bcl-2. Briefly, dentate gyrus samples after homogenization with lysis buffer were sonicated, boiled with gelloading buffer $(0.100 \mathrm{M}$ Tris-HCl; $4 \%$ SDS; $20 \%$ glycerol; $0.1 \%$ bromophenol blue) in the ratio $1: 1$, and protein concentrations were determined by the Bradford methods. Total protein equivalents (25-30 $\mu \mathrm{g}$ ) for each sample were separated by SDSPAGE by using $10 \%$ acrylamide gels and were transferred onto nitrocellulose membrane in a semidry transfer system. The membrane was immediately placed into blocking buffer containing $5 \%$ nonfat milk in $20 \mathrm{mM}$ Tris, pH 7.5; $150 \mathrm{mM} \mathrm{NaCl}$; and $0.01 \%$ Tween-20. The blot was allowed to block at $37^{\circ} \mathrm{C}$ for $1 \mathrm{~h}$. The membrane was incubated with rabbit polyclonal Bax, Bad, Bcl-2 and with goat polyclonal Mcl-1 (Gene Tex, Inc., CA, USA) $(1: 1,000)$ for $2 \mathrm{~h}$ at $25-27{ }^{\circ} \mathrm{C}$, followed by incubation in an anti-rabbit or anti-goat IgG-horseradish peroxidase conjugated antibody (1:4,000). After washing with T-TBS, the membranes were incubated with ECL Plus detection reagents (Amersham Life Science Inc., Buckinghamshire, UK), exposed to X-ray film. The films were scanned with densitometer (BioRad GS 800) to determine the relative optical densities. Prestained protein markers were used for molecular weight determinations.

\section{RNA isolation and RT-PCR}

RNA was isolated from dentate gyrus samples of male rats using the TRI Reagent Kit (Molecular Research Center, Inc., Cincinnati, OH), following the manufacturer's protocol. The purity of the RNA was estimated by $1.5 \%$ agarose gel electrophoresis, and RNA concentration was determined by spectrophotometry $(260 \mathrm{~nm})$. Reverse transcription of $2 \mu \mathrm{g}$ RNA for cDNA synthesis was performed using the Reverse Transcription System, (Promega, Madison, WI, USA) and a $\operatorname{pd}(\mathrm{N}) 6$ random hexamer. RT-PCR was performed in an Applied Biosystems 7300 apparatus using the SYBR Green PCR Master Mix (Applied Biosystems, Warrington, UK) and $300 \mathrm{nM}$ concentrations of specific primers (Table 1). The thermocycling

Table 1 Primers used in real-time PCR experiments

\begin{tabular}{|c|c|c|}
\hline Primers & & Sequence $\left(5^{\prime}-3^{\prime}\right)$ \\
\hline \multirow[t]{2}{*}{$18 \mathrm{~s}$} & Forward & GGTGCATGGCCGTTCTTA \\
\hline & Reverse & TCGTTCGTTATCGGAATTAACC \\
\hline \multirow[t]{2}{*}{$\mathrm{Bcl}-2$} & Forward & CAGGTATGCACCCAGAGTGA \\
\hline & Reverse & GTCTCTGAAGACGCTGCTCA \\
\hline \multirow[t]{2}{*}{ BAD } & Forward & GCCCTAGGCTTGAGGAAGTC \\
\hline & Reverse & CAAACTCTGGGATCTGGAACA \\
\hline \multirow[t]{2}{*}{ BAX } & Forward & GTGAGCGGCTGCTTGTCT \\
\hline & Reverse & GGTCCCGAAGTAGGAGAGGA \\
\hline \multirow[t]{2}{*}{ XIAP } & Forward & GCTTGCAAGAGCTGGATTTT \\
\hline & Reverse & TGGCTTCCAATCCGTGAG \\
\hline \multirow[t]{2}{*}{ AIF } & Forward & AGTCCTTATTGTGGGCTTATCAAC \\
\hline & Reverse & TTGGTCTTCTTTAATAGTCTTGTAGGC \\
\hline \multirow[t]{2}{*}{ NIAP } & Forward & GAGAGGTGGCACAGTCAGGT \\
\hline & Reverse & TAAAACGGCCAGTCCTCAAA \\
\hline \multirow{2}{*}{$\begin{array}{l}\text { Sirtuin } \\
2\end{array}$} & Forward & CCACTGTAACCACGTCTGCTC \\
\hline & Reverse & CAGTGTCCGAGTCTGAATCCT \\
\hline \multirow{2}{*}{$\begin{array}{l}\text { Sirtuin } \\
1\end{array}$} & Forward & TCGTGGAGACATTTTTAATCAGG \\
\hline & Reverse & GCTTCATGATGGCAAGTGG \\
\hline \multirow[t]{2}{*}{ IGF-I } & Forward & TGTCGTCTTCACATCTCTTCTACCTG \\
\hline & Reverse & CCACACACGAACTGAAGAGCGT \\
\hline
\end{tabular}

$18 \mathrm{~s}$ was used as a housekeeping gene to compare the samples 
profile conditions used were: $50{ }^{\circ} \mathrm{C}$ for $2 \mathrm{~m}, 95{ }^{\circ} \mathrm{C}$ for $10 \mathrm{~m}, 95{ }^{\circ} \mathrm{C}$ for $15 \mathrm{~s}, 60^{\circ} \mathrm{C}$ for $1 \mathrm{~m}, 95{ }^{\circ} \mathrm{C}$ for $15 \mathrm{~s}$, $60{ }^{\circ} \mathrm{C}$ for $30 \mathrm{~s}$ and $95{ }^{\circ} \mathrm{C}$ for $15 \mathrm{~s}$. For the normalization of cDNA loading in the PCR reaction, the amplification the 18S rRNA for every sample was used. Relative changes in gene expression were calculated using the $2-\Delta \Delta \mathrm{CT}$ method.

\section{Statistical analyses}

The results were statistically analyzed with the ANOVA method and a confidence level of $95 \%$ $(p<0.05)$ was considered significant. Results are expressed as the mean \pm SEM. Mean comparison was done by the ANOVA analysis of variance followed by a Fisher test.

\section{Results}

HSP 70 levels, which are known to prevent apoptosis, were decreased in the dentate gyrus of old male rats as compared to young ones $(p \leq 0.03)$. Administration of $\mathrm{GH}(p \leq 0.01)$ and melatonin $(p \leq 0.05)$ significantly elevated the levels of HSP 70 in hippocampus of old rats, with GH showing a more marked effect (Fig. 1).

The gene expressions of pro-apoptotic markers like $\operatorname{Bax}(p \leq 0.01)$ and $\operatorname{Bad}(p \leq 0.05)$ were increased in the dentate gyrus of old males as compared to young controls (Fig. 2). Melatonin treatment decreased the expression of $\operatorname{Bad}(p \leq 0.001)$ and $\operatorname{Bax}(p \leq 0.001)$ in dentate gyrus of old animals. However, GH was only able to diminish the mRNA expression of Bax ( $p \leq 0.001$ ), but not of Bad (Fig. 2).

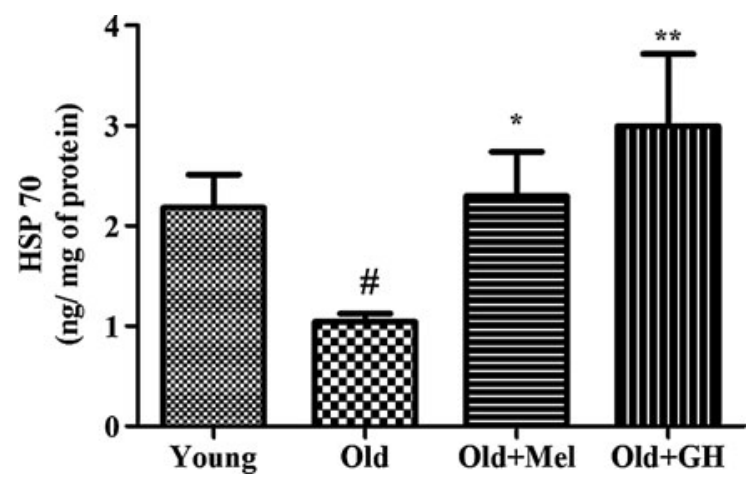

Fig. 1 Level of HSP 70 in dentate gyrus of young and old male rats and effect of chronical treatments with melatonin and $\mathrm{GH}$. Data represent mean \pm SEM
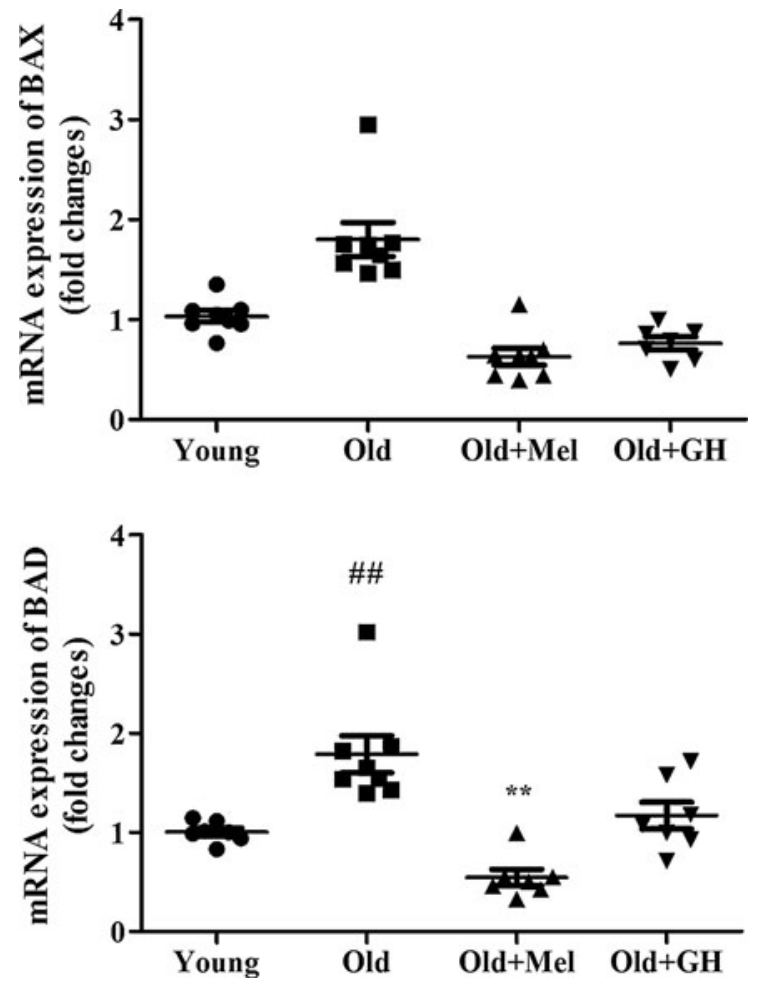

Fig. 2 mRNA $(n=7 / 8)$ expression of BAD and BAX in dentate gyrus of young and old male rats and effect of chronical treatments with melatonin and GH. Data represent mean \pm SEM

A slight age-related decrease of Bcl-2 expression in the dentate gyrus was evident in the study, but this trend did not show significant differences. When old rats were treated with $\mathrm{GH}$ or melatonin the expression of Bcl-2 did not show significant changes (Fig. 3). However, the Bcl-2/Bax ratio was higher in the group of young animals as compared to old and treatment with $\mathrm{GH}$ and melatonin were able to increase this parameter, thus showing that cells in this area of the hippocampus were protected from apoptosis.

The mRNA expressions of XIAP $(p \leq 0.05)$ and NIAP $(p \leq 0.05)$ were decreased in dentate gyrus of 24 month old when compared to 2 month old male rats (Fig. 4). When old males were treated with GH, significant increases of gene expression of XIAP $(p \leq 0.01)$ and NIAP $(p \leq 0.01)$ were observed. After chronic treatment with melatonin a significant increase in mRNA expression of NIAP $(p \leq 0.01)$ was detected, whereas XIAP expression did not show any change (Fig. 4). 


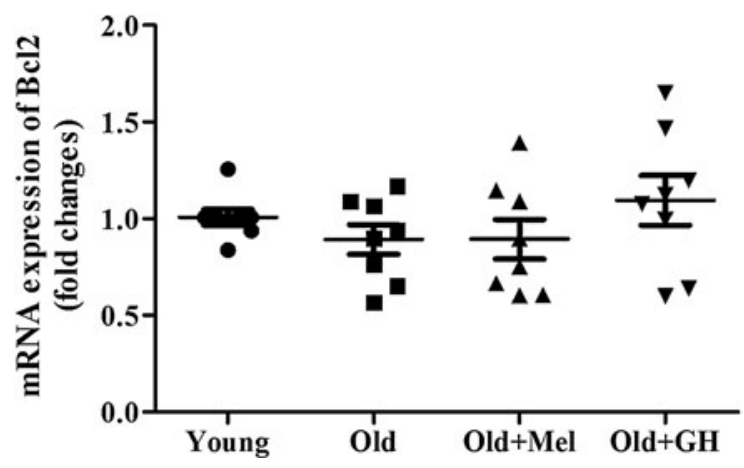

Fig. 3 mRNA $(n=7 / 8)$ expression of Bcl-2 in dentate gyrus of young and old male rats and effect of chronical treatments with melatonin and GH. Data represent mean \pm SEM
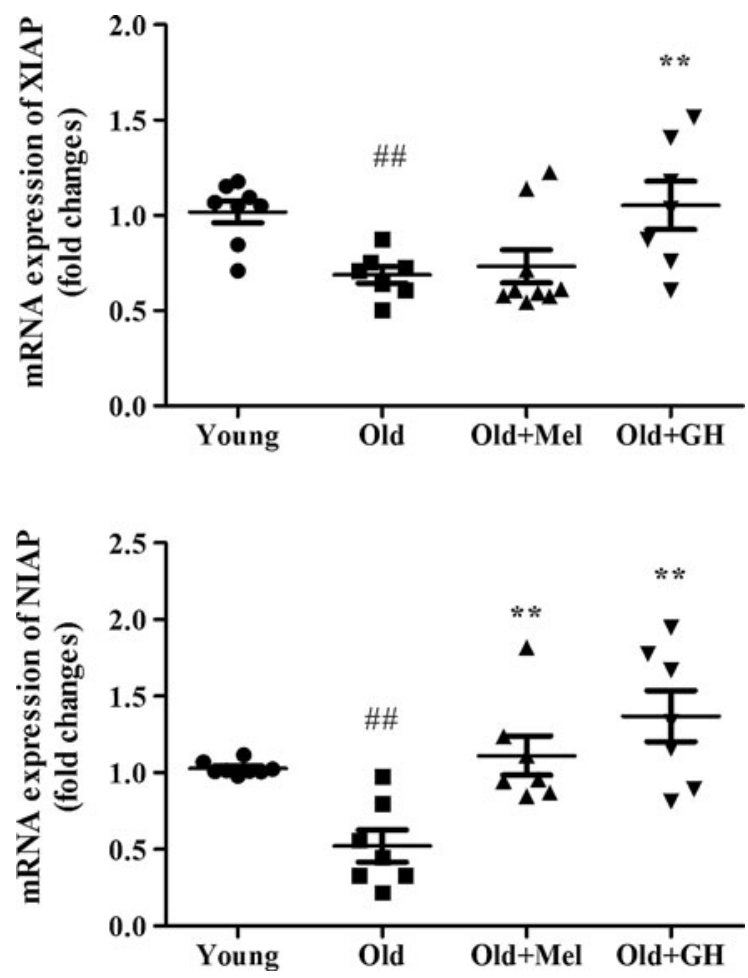

Fig. 4 Expression of mRNA XIAP and NIAP in the dentate gyrus of young and old male rats and effect of administration of melatonin and GH. Data represent mean $\pm \operatorname{SEM}(n=7 / 8)$

This hippocampus area of aged rats showed a highly significant increase in mRNA expression of apoptosisinducing factor (AIF) $(p \leq 0.001)$. Administration of melatonin and $\mathrm{GH}$ to old males significantly lowered its mRNA expression $(p \leq 0.01)$ (Fig. 5).

Aging induced also a significant decrease in the expression of SIRT1 $(p \leq 0.05)$ and $\operatorname{SIRT} 2(p \leq 0.05)$

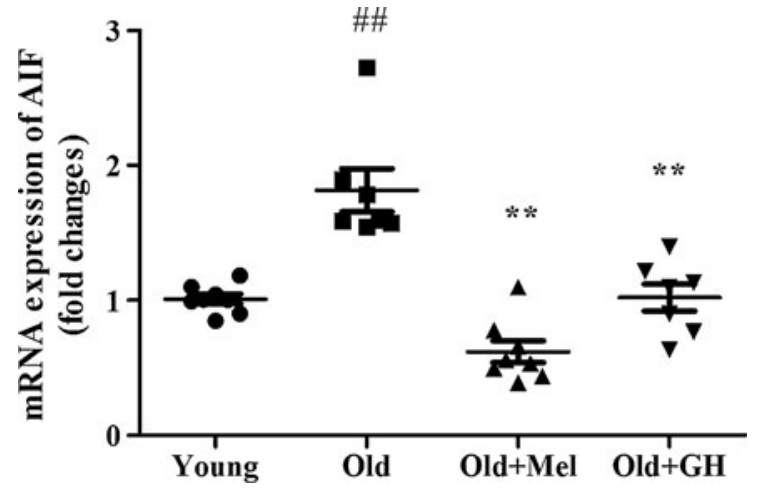

Fig. 5 Expression of mRNA AIF in the dentate gyrus of young and old male rats and effect of administration of melatonin and GH. Data represent mean $\pm \operatorname{SEM}(n=7 / 8)$

in the dentate gyrus (Fig. 6). The expression of SIRT2 gene was significantly up-regulated after GH replacement $(p \leq 0.05)$, but melatonin did not produce any effect on this parameter in the group of old male rats (Fig. 6). However, the mRNA expression of SIRT1 was significantly increased in the dentate gyrus of old males, but only after melatonin treatment $(p \leq 0.001)$ (Fig. 6).

Western blot results showed that $\operatorname{Bax}(p \leq 0.01)$ and $\operatorname{Bad}(p \leq 0.005)$ protein expressions were up regulated during aging (Fig. 7). When old animals were treated with melatonin, a significant reduction of both proteins could be observed ( $p \leq 0.01)$. However treatment with $\mathrm{GH}$ to old males was only able to reduce Bax protein $(p \leq 0.005)$ in the dentate gyrus (Fig. 7). Aging decreased the expression of Mcl-1 protein $(p \leq 0.05)$ and treatment with melatonin was able to significantly increase this parameter ( $p \leq 0.001$ ) (Fig. 8). In the case of $\mathrm{Bcl}-2$ protein, results obtained by Western blotting correlated with data obtained by PCR analysis. Bcl-2 protein levels demonstrated a tendency to decrease during aging, and treatments with $\mathrm{GH}$ and melatonin were not able to change this parameter (Fig. 9).

In addition, we also demonstrated that expression of IGFI was decreased in dentate gyrus of old male rats $(p \leq 0.02)$ and treatment with GH was able to significantly increase this parameter $(p \leq 0.02)$ (Fig. 10).

\section{Discussion}

In the present paper, we have demonstrated that aging induced significant increases in gene and protein 

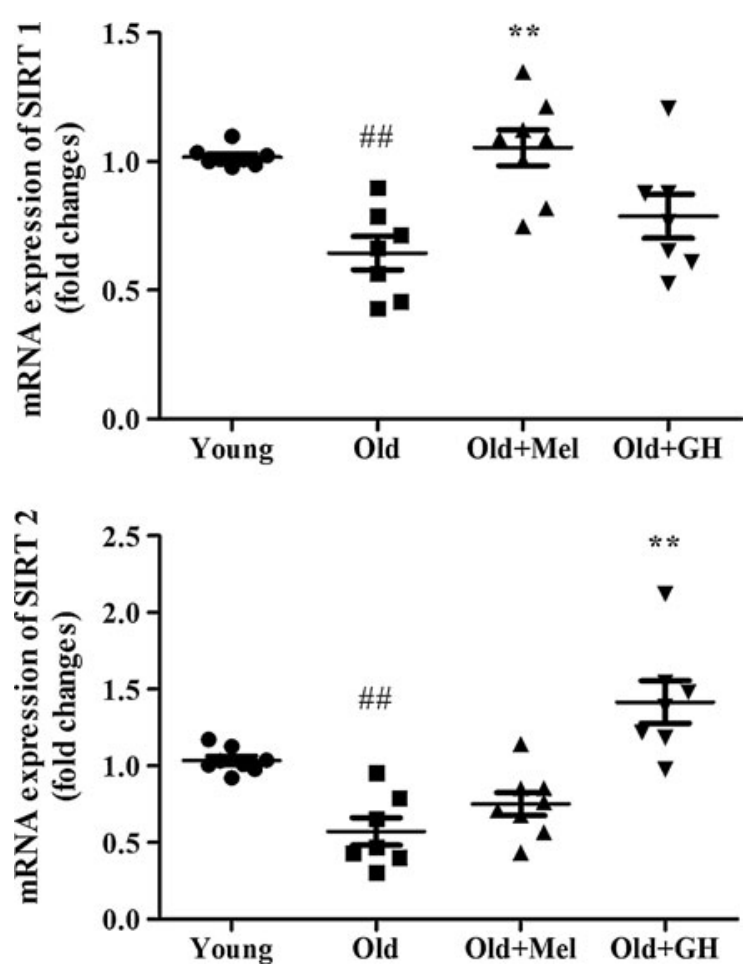

Fig. 6 The expression of mRNA SIRT1 and SIRT2 in the dentate gyrus of young and old male rats and effect of administration of melatonin and GH. Data represent mean \pm $\operatorname{SEM}(n=7 / 8)$

expressions of pro-apoptotic markers (Bax and $\mathrm{Bad}$ ) in the dentate gyrus of male rats. Tehranian et al. (2008) found that after cortical contusion injury Bax null mice were able to lose less hippocampal cells and showed increased hippocampal neurogenesis. Results obtained in our research are in accordance with data demonstrating that expressions of Bax and Bid protein in old-aged animals were significantly higher than in the young-control group (Thees et al. 2005; Kim et al. 2010). Our results also demonstrated an increase in the mRNA expression of AIF in the dentate gyrus of old rats and this could suggest, that this brain area was following different apoptotic pathways. Reix et al. (2007) reported that the "apoptotic-inducing" $57 \mathrm{kDa}$ isoform of AIF was increased with age and these authors suggest that the prevalence of AIF-dependent programmed cell death in cerebral cortex was also increased with age.

Another point of our research was the consequence of the expression of proteins and genes with opposite effects on apoptosis. So, we have demonstrated that during aging the expression of $\mathrm{Bcl}-2$ gene and proteins
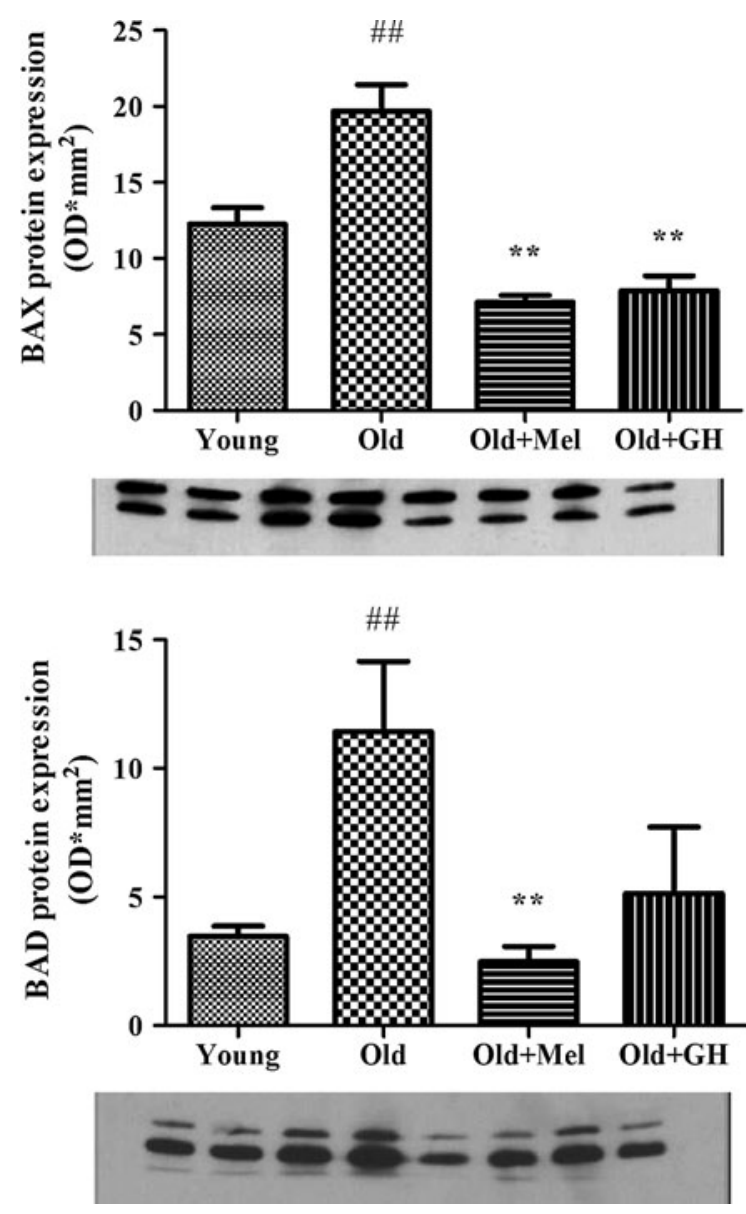

Fig. 7 Protein expression of BAD and BAX detected by Western blot in dentate gyrus of young and old male rats and effect of chronical treatments with melatonin and GH. Data represent mean \pm SEM $(n=4 / 5)$

did not change in the dentate gyrus of male Wistar rats. However, the $\mathrm{Bcl}-2 / \mathrm{Bax}$ ratio was significantly higher in the group of young animals as compared with old, indicating a lower level of apoptosis. The Bax/Bcl-2 balance was one of the critical factors determining whether the cells showed undergo apoptosis, and this balance was actually altered during aging (Thees et al. 2005). Interestingly, our present findings indicated that during aging the protein expression of Mcl-1 was decreased, but no changes in the expression of Bcl-2 gene and protein in the dentate gyrus were detected. Yang et al. (2012) demonstrated significant reduction in Mcl-1 expression at both the mRNA and the protein levels and the ratio of expression levels of Mcl-1/Bax genes in the aging subjects. Rapid reduction of Mcl-1 mRNA and protein levels are early events after DNA 

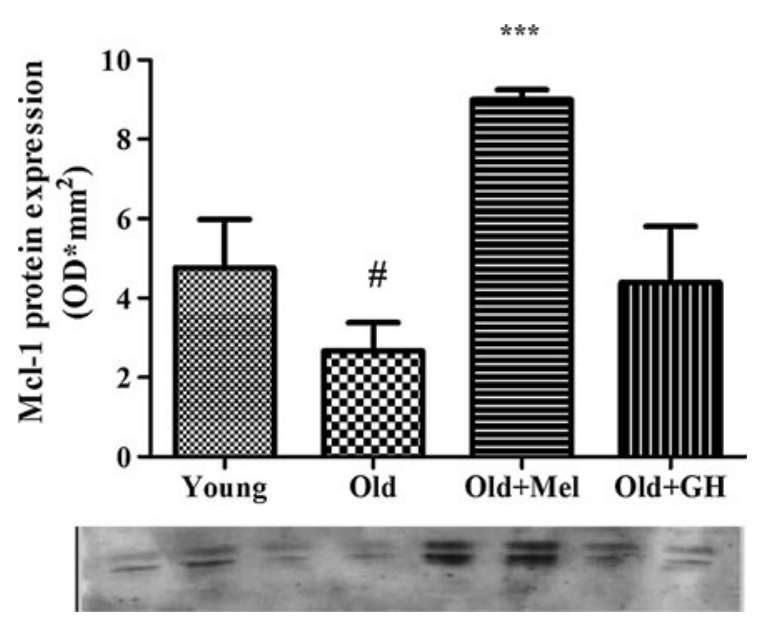

Fig. 8 Western blot analysis of Mcl-1 protein expression in the dentate gyrus of young and old male rats and effect of administration of melatonin and GH. Data represent mean \pm $\operatorname{SEM}(n=4 / 5)$
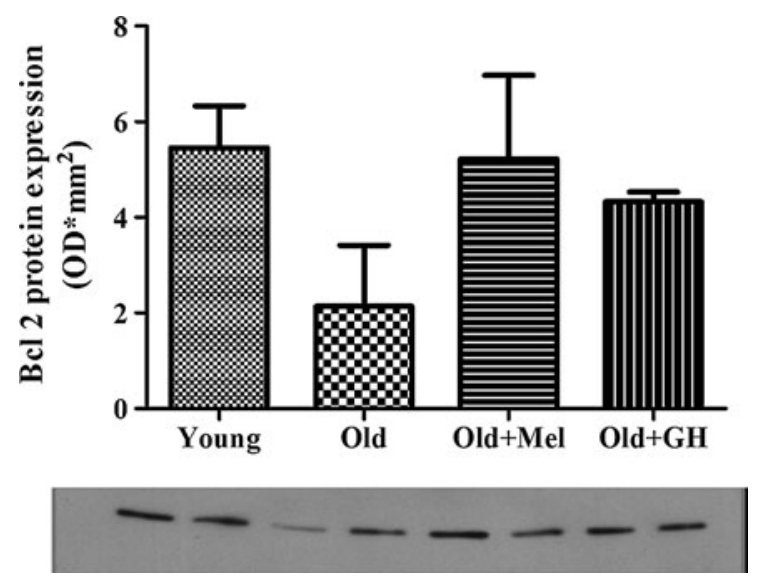

Fig. 9 Protein expression of Bcl-2 detected by Western blot in the dentate gyrus of young and old male rats and effect of administration of melatonin and GH. Data represent mean \pm $\operatorname{SEM}(n=4 / 5)$

damage in neurons, and maintaining high Mcl-1 levels can protect neurons against death (Arbour et al. 2008).

The present study demonstrated that aging was able to affect negatively the gene expression of XIAP and NIAP in the dentate gyrus of old male rats. In vitro studies reported that upregulation of NIAP and decreased interaction of NIAP with its endogenous inhibitor, Smac, by the presence of neurotrophin-3, did actually protected neurons from $\mathrm{A} \beta$ induced death (Lesné et al. 2005). Trapp et al. (2003) reported that transgenic XIAP-overexpressing mice showed

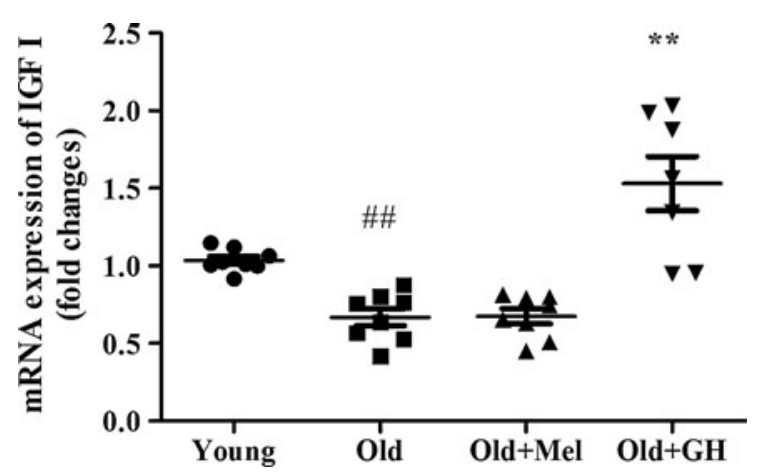

Fig. 10 The expression of mRNA IGF1 in the dentate gyrus of young and old male rats and effect of administration of melatonin and GH. Data represent mean $\pm \operatorname{SEM}(n=7 / 8)$

reduced caspase- 3 activation and fewer cells with DNA fragmentation.

The brain is exposed to chronic oxidative stress during aging (Rastogi et al. 2012). As result, there is a gradual accumulation of damaged proteins and a functional decline in the brain's endogenous defense system (Rumora et al. 2007; Min et al. 2008). Our results clearly indicated that levels of HSP 70 were decreased in the dentate gyrus of old male rats. These findings are in consonance with the results obtained by Pardue et al. (1992) and Galli et al. (2006), in which HSP 70 induction and constitutive HSC 70 values are lower with age in hippocampus. Other authors demonstrated that HSP 72 blocked apoptosis primarily by inhibiting translocation of the pro-apoptotic Bcl-2 family member Bax, thereby preventing the release of pro-apoptotic factors from mitochondria (Stankiewicz et al. 2005) and inhibiting AIF translocation to the nucleus (Matsumori et al. 2005).

Our data showed that the expression of SIRT1 was decreased in the dentate gyrus of old rats. A decrease in extracellular signal-regulated kinase $1 / 2$ phosphorylation and altered expression of hippocampal genes involved in synaptic function, lipid metabolism, and myelinization were also detected in SIRT1-KO mice. By contrast, mice with high levels of SIRT1 expression in the brain exhibited normal synaptic plasticity and memory (Michán et al. 2010). Pallàs et al. (2008) have demonstrated in the senescence-accelerated prone mice (SAMP-8), a progressively decreased SIRT1 expression. Lafontaine-Lacasse et al. (2010) have shown that Sirt1 mRNA levels were strongly decreased by aging in the arcuate nucleus. It has been also reported that specific activity of SIRT1 was 
decreased with aging and this could impact the ageassociated protein acetylation levels in the cerebellum (Marton et al. 2010). SIRT2 has been related to synaptic plasticity, learning and memory that are also in turn related to neuronal motility and migration. SIRT2 has also been implicated in neuronal growth cone motility (Harting and Knoll 2010). The data presented here, showed significantly decreased SIRT2 expressions in the dentate gyrus of old male rats.

In our study $\mathrm{GH}$ administration was found to increase expression on XIAP, NIAP, SIRT2 and HSP 70 levels and to decrease the expression of proapoptotic markers like Bax and AIF. These results demonstrated that $\mathrm{GH}$ was able to regulate different (extrinsic and intrinsic) pathways of the apoptotic process in the dentate gyrus of old male rats. The mechanism of regulation of apoptosis by GH could be direct or in-direct, via induction of IGF-1 production and in the literature several results seemed to confirm this. We have demonstrated that the mRNA expression of IGF-1 that showed an age associated decrease in the dentate gyrus in male rats could be restored by $\mathrm{GH}$ treatment. Thus restoration of physiological levels of GH/IGF-1 axis was able to influence on the molecular pathways that lead to a reduction in apoptosis. Mechanisms underlying GH-mediated regulation of apoptosis include activation of the phosphatidylinositol 3-kinases (PI3K)-Akt pathway (Jeay et al. 2002), reduction of Bax (Kolle et al. 2002) and increasing Bcl-2 expression (Haeffner et al. 1999). Treatment with GH decreased LDH release, Bax/caspase-3 activity and increased $\mathrm{Bcl}-2$ expression compared with $\mathrm{A} \beta$ treatment in a human neuroblastoma cell line (Zhang et al. 2010). Svensson et al. (2008) also found that treatment with $\mathrm{GH}$ is capable of preventing or even repairing morphine-induced damage to hippocampal cells by decreasing the caspase- 3 activity and increasing the neuronal cell density. Reduction of apoptosis has also been shown by our group to have a positive effect on behavior in old male rats like memory tasks performed in the radial maze and motor ability in the Rotarod treadmill (Esteban et al. 2010). GH improved working memory processes through both NMDA and AMPA glutamatergic receptors and it required the activation of extracellular MEK/ERK signalling pathway. These effects could be related to the enhancement of excitatory synaptic transmission in the hippocampus reported by GH administration (Ramis et al. 2013).
Besides exhibiting well known antioxidant properties, melatonin also has been shown to protect neuronal cells from oxidative stress and apoptosis as induced by mitochondrial DNA deletion (Alvira et al. 2006; Jou et al. 2007). An important observation of the present study is that chronic treatment with melatonin did actually reduce the expression of Bax and Bad in the dentate gyrus of old male rats. These findings together with previous results indicating that melatonin was able to inhibit $\mathrm{H}_{2} \mathrm{O}_{2}$-induced apoptosis in cultured rat astrocytes, point to its ability to down regulate Bax expression and to inhibit caspase-3 activation (Juknat et al. 2005). Baydas et al. (2005) found that chronic melatonin administration markedly reduced the hyperhomocysteinemia-induced rise in mitochondrial Bax levels, restoring cytosolic Bax values and inhibiting caspase-9 activation in the hippocampus. In Tg mice (a model of Alzheimer's disease) early melatonin supplementation, prevented the abnormal upregulation of Bax, caspase- 3 and Par- 4 (prostate apoptosis response-4) in cortex neurons (Feng et al. 2006). The other, possible, mechanism of action of melatonin is its upregulation of antiapoptotic proteins, as has been demonstrated by several authors. So, melatonin increased Bcl-2 and augmented expression of XIAP in ethanol-treated HN2-5 (mouse hippocampal neuron-derived) cells (Shetha et al. 2009). Nopparat et al. (2010) have demonstrated, in the SK-N-SH dopaminergic cell line, a novel role of melatonin in protecting cells from autophagic cell death triggered by the Bcl-2/Beclin 1 pathway, inhibiting the activation of the JNK1 (c-Jun amino-terminal kinase), Bcl-2 upstream pathway. In the present study, melatonin treatment was not able to change the expression of Bcl-2 and XIAP, but significantly increased gene expression of NIAP, Mcl-1 protein levels and could maintain a favourable B-cell lymphoma 2 (Bcl-2)/Bax ratio in the dentate gyrus of old rats. In addition, we have also observed that melatonin was able to decrease mRNA expression of AIF. Our data were in agreement with previous reports in which melatonin was able to prevent the insult related release of AIF from mitochondria (Andrabi et al. 2004). One of the most important changes that we have observed in aged dentate gyrus after melatonin treatment was the increase in the expression of SIRT1, which was consistent with finding by Gutierrez-Cuesta et al. (2008), who examined the effects of melatonin stimulating survival 
processes in senescence-accelerated (SAMP8) and resistant mice (SAMR1). The same group has also demonstrated that melatonin exerted a neuroprotective role through the SIRT1 pathway (Tajes et al. 2009).

In conclusion, aging in the dentate gyrus is associated with increased expression of pro-apoptotic genes and proteins, like Bax, Bad, AIF and decreased anti-apoptotic ones such as Mcl-1, XIAP and NIAP. We reported also a decrease in expression of SIRT1 and SIRT2 in the dentate gyrus of old male rats. Both treatments have been shown to modulate the proantiapoptotic ratio and increase sirtuins expression restoring the situation found in young animals. Our data demonstrated that melatonin and growth hormone could exert a protective effect on hippocampal damage induced by aging. Further studies of the survival signalling pathways may provide novel therapeutic strategies for preventive of age-related disease to prevent age-related alterations.

Acknowledgments This work was supported by grants: RETICEF RD 06/0013 (FIS) Instituto Carlos IIIand SAF 2007, 66878-C02-01.

Open Access This article is distributed under the terms of the Creative Commons Attribution License which permits any use, distribution, and reproduction in any medium, provided the original author(s) and the source are credited.

\section{References}

Allsopp TE, Wyatt S, Paterson HF, Davies AM (1993) The proto-oncogene $\mathrm{Bcl}-2$ can selectively rescue neurotrophic factor-dependent neurons from apoptosis. Cell 73:295-307

Alvira D, Tajes M, Verdaguer E, Acuna-Castroviejo D, Folch J, Camins A, Pallas M (2006) Inhibition of the cdk5/p25 fragment formation may explain the antiapoptotic effects of melatonin in an experimental model of Parkinson's disease. J Pineal Res 40:251-258

Ambacher KK, Pitzul KB, Karajgikar M, Hamilton A, Ferguson SS, Cregan SP (2012) The JNK- and AKT/GSK3 $\beta$ - signalling pathways converge to regulate Puma induction and neuronal apoptosis induced by tropic factor deprivation. PLoS ONE 7(10):e46885

Andrabi SA, Sayeed I, Siemen D, Wolf G, Horn TF (2004) Direct inhibition of the mitochondrial permeability transition pore: a possible mechanism responsible for antiapoptotic effects of melatonin. FASEB J 18:869-871

Arbour N, Vanderluit JL, Le Grand JN, Jahani-Asl A, Ruzhynsky VA, Cheung ECC, Kelly MA, MacKenzie AE, Park DS, Opferman JT, Slack RS (2008) Mcl-1 is a key regulator of apoptosis during CNS development and following DNA damage. J Neurosci 28(24):6068-6078
Azcoitia I, Perez-Martin M, Salazar V, Castillo C, Ariznavarreta C, Garcia-Segura LM, Tresguerres JAF (2005) Growth hormone prevents neuronal loss in the aged rat hippocampus. Neurobiol Aging 26:697-703

Baydas G, Reiter RJ, Akbulut M, Tuzcu M, Tamer S (2005) Melatonin inhibits neural apoptosis induced by homocysteine in hippocampus of rats via inhibition of cytochrome $\mathrm{c}$ translocation and caspase- 3 activation and by regulating pro- and anti-apoptotic protein levels. Neuroscience 135:879-886

Chan WY, Lorke DE, Tiu SC, Yew DT (2002) Proliferation and apoptosis in the developing human neocortex. Anat Rec 267:261-276

Cohen HY, Lavu S, Bitterman KJ, Hekking B, Imahiyerobo TA, Miller C (2004) Acetylation of the $\mathrm{C}$ terminus of Ku70 by CBP and PCAF controls Bax-mediated apoptosis. Mol Cell 13:627-638

Esteban S, Garau C, Aparicio S, Moranta D, Barceló P, Ramis M, Tresguerres JA, Rial R (2010) Improving effects of long-term growth hormone treatment on monoaminergic neurotransmission and related behavioral tests in aged rats. Rejuvenation Res 13(6):707-716

Feng Z, Qin C, Chang Y, Zhang J (2006) Early melatonin supplementation alleviates oxidative stress in a transgenic mouse model of Alzheimer's disease. Free Radical Biol Med 40:101-109

Galli RL, Bielinski DF, Szprengiel A, Shukitt-Hale B, Joseph A (2006) Blueberry supplemented diet reverses age-related decline in hippocampal HSP70 neuroprotection. Neurobiol Aging 27(2):344-350

Ghigo E, Arvat E, Gianotti L, Lanfranco F, Broglio F, Aimaretti G, Maccario M, Camami F (2000) Hypothalamic growth hormone-insulin-like growth factor-I axis across the human life span. J Pediatr Endocrinol Metab 13:1493-1502

Gutierrez-Cuesta J, Tajes M, Jimenez A (2008) Evaluation of potential pro-survival pathways regulated by melatonin in a murine senescence model. J Pineal Res 45:497-505

Haeffner A, Deas O, Mollereau B, Estaquier J, Mignon A, Haeffner-Cavaillon N, Charpentier B, Senik A, Hirsch F (1999) Growth hormone prevents human monocytic cells from Fas-mediated apoptosis by up-regulating Bcl-2 expression. Eur J Immunol 29:334-344

Hagihara H, Toyama K, Yamasaki N, Miyakawa T (2009) Dissection of hippocampal dentate gyrus from adult mouse. J Vis Exp 17(33):e1543. doi:10.3791/1543

Harting K, Knoll B (2010) SIRT2-mediated protein deacetylation: an emerging key regulator in brain physiology and pathology. Eur J Cell Biol 89:262-269

Jeay S, Sonenshein GE, Postel-Vinay MC, Kelly PA, Baixeras E (2002) Growth hormone can act as a cytokine controlling survival and proliferation of immune cells: new insights into signaling pathways. Mol Cell Endocrinol 188:1-7

Jou MJ, Peng TI, Yu PZ, Jou SB, Reiter RJ, Chen JY, Wu HY, Chen CC, Hsu LF (2007) Melatonin protects against common deletion of mitochondrial DNA-augmented mitochondrial oxidative stress and apoptosis. J Pineal Res 243:389-403

Juknat AA, Mendez MdelV, Quaglino A, Farmeli CI, Mena M, Kotler ML (2005) Melatonin prevents hydrogen peroxideinduced Bax expression in cultured rat astrocytes. J. Pineal Res 38(2):84-92 
Kadish IBC, Thibault O, Blalock EM, Chen KC, Gant JC, Porter NM, Landfield PW (2009) Hippocampal and cognitive aging across the lifespan: a bioenergetic shift precedes and increased cholesterol trafficking parallels memory impairment. J Neurosci 29(6):1805-1816

Kim WR, Sun W (2011) Programmed cell death during postnatal development of the rodent nervous system. Develop. Growth Differ. 53:225-235

Kim D, Nguyen MD, Dobbin MM, Fischer A, Sananbenesi F, Rodgers JT, Delalle I, Baur JA, Sui G, Armour SM, Puigserver P, Sinclair DA, Tsai LH (2007) SIRT1 deacetylase protects against neurodegeneration in models for Alzheimer's disease and amyotrophic lateral sclerosis. EMBO J 26:3169-3179

Kim SE, Ko LG, Kim BK, Shin MS, Cho S, Kim CJ, Kim SH, Baek SS, Lee EK, Jee YS (2010) Treadmill exercise prevents aging-induced failure of memory through an increase in neurogenesis and suppression of apoptosis in rat hippocampus. Exp Gerontol 45:357-365

Kolle S, Stojkovic M, Boie G, Wolf E, Sinowatz F (2002) Growth hormone inhibits apoptosis in vitro produced bovine embryos. Mol Reprod Dev 61:180-186

Kwon HS, Ott M (2008) The ups and downs of SIRT1. Trends Biochem Sci 33:517-525

Lafontaine-Lacasse M, Richard D, Picard F (2010) Effects of age and gender on Sirt 1 mRNA expressions in the hypothalamus of the mouse. Neurosci Lett 480:1-3

Lai Z, Roos P, Zhai Q, Olsson Y, Fholenhag K, Larsson C, Nyberg F (1993) Age-related reduction in human growth hormone binding sites in the human brain. Brain Res 621: 260-266

Laudon M, Nir I, Zisapel N (1988) Melatonin receptors in discrete brain areas of the male rat. Impact of aging on density and on circadian rhythmicity. Neuroendocrinology 48:577-583

Lein Ed S, Zhao X, Gage FH (2004) Defining a molecular atlas of the hippocampus using DNA microarrays and highthroughput in situ hybridization. J Neurosci 24(15): 3879-3889

Lesné S, Gabriel C, Nelson DA, White E, MacKenzie ET, Vivien D, Buisson A (2005) Akt-dependent expression of NAIP-1 protects neurons against amyloid-\{beta $\}$ toxicity. J Biol Chem 280:24941-24947

Marton O, Koltai E, Nyakas C, Bakonyi T, Zenteno-Savin T, Kumagai S, Goto S, Radak Z (2010) Aging and exercise affect the level of protein acetylation and SIRT1 activity in cerebellum of male rats. Biogerontology 11(6):679-686

Matsumori Y, Hong SM, Aoyama K, Fan Y, Kayama T, Sheldon RA, Vexler ZS, Ferriero DM, Weinstein PR, Liu J (2005) Hsp70 overexpression sequesters AIF and reduces neonatal hypoxic/ischemic brain injury. J Cereb Blood Flow Metab 25:899-910

Mattson MP (2006) Neuronal life-and-death signalling, apoptosis, and neurodegenerative disorders. Antioxid Redox Signal 8(11):1997-2006

Michán S, Li Y, Chou MM, Parrella E, Ge H, Long JM, Allard JS, Lewis K, Miller M, Xu W, Mervis RF, Chen J, Guerin KI, Smith LE, McBurney MW, Sinclair DA, Baudry M, de Cabo R, Longo VD (2010) SIRT1 is essential for normal cognitive function and synaptic plasticity. J Neurosci 30(29):9695-9970
Min JN, Whaley RA, Sharpless NE, Lockyer P, Portbury AL, Patterson C (2008) CHIP deficiency decreases longevity, with accelerated aging phenotypes accompanied by altered protein quality control. Mol Cell Biol 28:4018-4025

Mordenti J, Chappell W (1989) The use of interspecies scaling in toxicokinetics. In: Yacobi A, Kelly J, Batra V (eds) Toxicokinetics and new drug development. Pergamon, New York, pp 42-96

Musshoff U, Riewenherm D, Berger E, Fauteck JD, Speckmann EJ (2002) Melatonin receptors in rat hippocampus: molecular and functional investigations. Hippocampus 12: 165-173

Nass R, Johannsson G, Christiansen JS, Kopchick JJ, Thorner MO (2009) The aging population-Is there a role for endocrine interventions? Growth Horm IGF Res 19: 89-100

Nieves-Martinez E, Sonntag WE, Wilson A, Donahue A, Molina DP et al (2010) Early-onset GH deficiency results in spatial memory impairment in midlife and is prevented by GH supplementation. J Endocrinol 204:31-36

Nopparat C, Porter JE, Ebadi M, Govitrapong P (2010) The mechanisms for the neuroprotective effect of melatonin against methamphetamine-induced autophagy. J Pineal Res 49(4):382-389

Ota K, Yakovlev AG, Itaya A, Kameoka M, Tanaka Y, Yoshihara K (2002) Alteration of apoptotic protease-activating' factor-1 (APAF-1)-dependent apoptotic pathway during development of rat brain and liver. J Biochem (Tokyo) 131:131-135

Pallàs M, Pizarro JG, Gutierrez-Cuesta J, Crespo-Biel N, Alvira D, Tajes M, Yeste-Velasco M, Folch J, Canudas AM, Sureda FX, Ferrer I, Camins A (2008) Modulation of SIRT1 expression in different neurodegenerative models and human pathologies. Neuroscience 154:1388-1397

Pandi-Perumal SR, Trakht I, Srinivasan V, Spence DW, Maestroni GJM, Zisapel N, Cardinali DP (2008) Physiological effects of melatonin: role of melatonin receptors and signal transduction pathways. Prog Neurobiol 85:335-353

Pardue S, Groshan K, Raese JD, Morrison-Bogorad M (1992) Hsp 70 mRNA induction is reduced in neurons of aged rat hippocampus after thermal stress. Neurobiol Aging 13:661-672

Prunell GF, Troy CM (2004) Balancing neuronal death. J Neurosci Res 78:1-6

Quik EH, van Dam PS, Kenemans JL (2010) Growth hormone and selective attention: a review. Neurosci Biobehav Rev 34:1137-1143

Ramis M, Sarubbo F, Sola J, Aparicio S, Garau C, Miralles A, Esteban S (2013) Cognitive improvement by acute growth hormone is mediated by NMDA and AMPA receptors and MEK pathway. Prog Neuropsychopharmacol Biol Psychiatry 45:11-20

Rastogi M, Ojha RP, Prabu PC, Devi BP, Agrawal A, Dubey GP (2012) Prevention of age-associated neurodegeneration and promotion of healthy brain ageing in female Wistar rats by long term use of bacosides. Biogerontology 13:183-195

Reix S, Mechawar N, Susin SA, Quirion R, Krantic S (2007) Expression of cortical and hippocampal apoptosis-inducing factor (AIF) in aging and Alzheimer's disease. Neurobiol Aging 28:351-356 
Rosenzweig ES, Barnes CA (2003) Impact of aging on hippocampal function: plasticity, network dynamics, and cognition. Prog Neurobiol 69:143-179

Rowe WB, Blalock EM, Chen KC, Kadish I, Wang D, Barrett JE, Thibault O, Porter NM, Rose GM, Landfield PW (2007) Hippocampal expression analyses reveal selective association of immediate-early, neuroenergetic, and myelinogenic pathways with cognitive impairment in aged rats. J Neurosci 27:3098-3110

Rumora L, Lovric J, Sairam MR, Maysinger D (2007) Impairments of heat shock protein expression and MAPK translocation in the central nervous system of follitropin receptor knockout mice. Exp Gerontol 42:619-628

Sanders EJ, Lin WY, Parker E, Harvey S (2010) Growth hormone expression and neuroprotective activity in a quail neural retina cell line. Gen Comp Endocrinol 165:111-119

Shen YX, Xu SY, Wei W (2002) Melatonin blocks rat hippocampal neuronal apoptosis induced by amyloid beta-peptide 25-35. J Pineal Res 32(3):163-167

Shetha DS, Tajuddin NF, Druse MJ (2009) Antioxidant neuroprotection against ethanol-induced apoptosis in HN2-5 cells. Brain Res 1285:14-21

Sonntag WE, Carter CS, Ikeno Y, Ekenstedt K, Carlson CS, Loeser RF, Chakrabarty S, Lee S, Bennett C, Ingram R et al (2005) Adult-onset growth hormone and insulin-like growth factor I deficiency reduces neoplastic disease, modifies age-related pathology, and increases life span. Endocrinology 146:2920-2932

Stankiewicz AR, Lachapelle G, Foo CP, Radicioni SM, Mosser DD (2005) Hsp70 inhibits heat-induced apoptosis upstream of mitochondria by preventing Bax translocation. J Biol Chem 280:38729-38739

Svensson AL, Bucht N, Hallberg M, Nyberg F (2008) Reversal of opiate-induced apoptosis by human recombinant growth hormone in murine foetus primary hippocampal neuronal cell cultures. Proc Natl Acad Sci USA 105(20):7304-7308
Tajes M, Gutierrez-Cuesta J, Ortuño-Sahagun D, Camins A, Pallas M (2009) Anti-aging properties of melatonin in an in vitro murine senescence model: involvement of the sirtuin 1 pathway. J Pineal Res 47(3):228-237

Tehranian R, Rose ME, Vagni V, Pickrell AM, Griffith RP, Liu H, Clark RS, Dixon CE, Kochanek PM, Graham SH (2008) Disruption of Bax protein prevents neuronal cell death but produces cognitive impairment in mice following traumatic brain injury. J Neurotrauma 25(7):755-767

Thees S, Hubbard GB, Winckler J, Schultz C, Rami A (2005) Specific alteration of the $\mathrm{Bax} / \mathrm{Bcl} 2$ ratio and cytochrome $\mathrm{c}$ without execution of apoptosis in the hippocampus of aged baboons. Restor Neurol Neurosci 23:1-9

Trapp T, Korhonen L, Besselmann M, Martinez R, Mercer EA, Lindholm D (2003) Transgenic mice overexpressing XIAP in neurons show better outcome after transient cerebral ischemia. Mol Cell Neurosci 23:302-313

Tresguerres JA, Kireev R, Tresguerres AF, Borras C, Vara E, Ariznavarreta C (2008) Molecular mechanisms involved in the hormonal prevention of aging in the rat. J Steroid Biochem Mol Biol 108(3-5):318-326

Troy CM, Akpan N, Jean YY (2011) Regulation of caspase in the nervous system implications for functions in health and disease. Prog Mol Biol Transl Sci 99:265-305

Yang WP, Guo WW, Liu HZ, Xu Y, Chen L, Hu BH (2012) Age-related changes in the ratio of Mcl-1/Bax expression in the rat cochlea. Acta Otolaryngol 132(2):123-132

Yoo YM, Yim SV, Kim SS (2002) Melatonin suppresses NOinduced apoptosis via induction of $\mathrm{Bcl}-2$ expression in PGT-beta immortalized pineal cell. J Pineal Res 33(3):146-150

Zhang T, Qu H, Li X, Zhao B, Zhou J, Li Q, Sun M (2010) Transmembrane delivery and biological effect of human growth hormone via a phage displayed peptide in vivo and in vitro. J Pharm Sci 99(12):4880-4891 